\title{
Sewage Sludge: An Important Biological Resource for Sustainable Agriculture and Its Environmental Implications
}

\author{
Khalid Usman $^{1 *}$, Sarfaraz Khan², Said Ghulam³, Muhammad Umar Khan ${ }^{4}$, Niamatullah Khan, \\ Muhammad Anwar Khan ${ }^{1}$, Shad Khan Khalil ${ }^{5}$ \\ ${ }^{1}$ Department of Agronomy, Faculty of Agriculture, Gomal University, Dera Ismail Khan, Pakistan; ${ }^{2}$ University Wensam College, \\ Gomal University, Dera Ismail Khan, Pakistan; ${ }^{3}$ Department of Soil Science, Faculty of Agriculture, Gomal University, Dera Ismail \\ Khan, Pakistan; ${ }^{4}$ Department of Agriculture Chemistry, Faculty of Agriculture, Gomal University, Dera Ismail Khan, Pakistan; \\ ${ }^{5}$ Department of Agronomy, Agricultural University, Peshawar, Pakistan. \\ Email: *marwat7862003@yahoo.com
}

Received August 19 ${ }^{\text {th }}$, 2012; revised September $18^{\text {th }}$, 2012; accepted September $26^{\text {th }}, 2012$

\begin{abstract}
Intensive farming generally needs large addition of organic matter to maintain fertility and enhance crop yields. Sewage sludge/biosolids are by-products of municipal and industrial wastewater treatment and a rich source of organic nutrients. Sewage sludge having high content of organic matter, macro- and micro-nutrients, can be used as fertilizer/soil conditioner for food, vegetable crop, horticultural plants and pasture, which in most cases can be beneficially recycled. In the past sewage sludge was regarded as a waste product due to expected high level of contaminants such as pathogens, pollutants and synthetic materials discharged in sewer from homes and industries, which were often incinerated, dumped in occasion or land fill. As a result of rapidly increasing population, urbanization and industrialization, wastewater production and sewage sludge generation have increased manifold. Due to high cost of mineral fertilizers and escalating trends in their prices, there is an increasing trend of using sewage sludge in agriculture, especially under intensive cropping in arid and semi arid regions of the country. Therefore, application of sewage sludge to agricultural soils may be sustainable and economical due to nutrient cycling and disposal of sewage sludge. However, there may be a risk in use of sewage sludge due to potentially harmful contents present in the sludge such as heavy metals and pathogens. This paper, therefore, presents a review on various aspects of sewage sludge used in agriculture.
\end{abstract}

Keywords: Sewage Sludge; Sustainable Agriculture; Pathogen; Heavy Metals; Soil Quality and Fertility

\section{Introduction}

Sewage sludge consists of by-products of wastewater treatment. It is a mixture of water, inorganic and organic materials removed from wastewater coming from various sources (domestic sewage, industries), storm water runoff from roads and other paved area, through physical, biological, and/or chemical treatments. Sewage sludge is also referred to as biosolids. Various agencies have put forth different definitions of Biosolids. Biosolids are nutrients rich organic materials resulting from the treatment of domestic sewage in a treatment facility [1]. Some regards biosolids as stabilized organic solids derived from biological wastewater treatment process, which can be managed safely to utilize their nutrients on sustainable basis, and used for soil conditioning, energy, or other value [2]. The utilization of biosolids/sewage sludge in

*Corresponding author. agriculture is gaining popularity as a source of waste disposal. Biosolids/sewage sludge generally contain useful compounds of potential environmental value. They also contain useful concentration of organic matter, nitrogen, phosphorus and potassium and to lesser extent, calcium, sulphur and magnesium. The availability of phosphorus content in the year of application to agricultural lands is above $50 \%$ and is independent of prior sludge treatment. Nitrogen availability is more dependent on sludge treatment. Untreated liquid sludge and dewatered treated sludge release nitrogen slowly with benefits to crop being realized over a relatively long period. Anaerobically digested sludge has high contents of ammonia, which is readily available to plants. Thus it is a nutrient enriched fertilizer. The organic matter content in sludge can improve soil physical, chemical, and biological properties with ensuring better cultivation and aquiferous capacity of soil [3], especially when applied in the 
form of dewatered sludge cake [4]. Biosolids reduce runoff and increase surface retention of rain water [5]. Organic nitrogen in sludge is much less likely to cause ground water pollution than chemical nitrogen fertilizer [6]. The application of sewage sludge to agricultural land is the best way of recycling the nutrients present in it. Therefore, sewage sludge may be considered an important biological resource for sustainable agriculture. It produces favorable plant yield responses, when used as an organic fertilizer $[7,8]$.

The only drawback in the use of sewage sludge on agricultural land is its pollutant load (including heavy metals, organic compounds, pharmaceuticals and pathogens). Potentially toxic elements, is a general term for wide range of metals that originate in sewage, such as cadmium, copper, nickel, lead, zinc, mercury and chromium. The metals are concentrated in the sludge as a result of their association with settable solids during primary and secondary treatment process [9]. Research on land application of sewage sludge has mainly focused on its role in introduction of heavy metals in the food chain. However, it has been shown that sewage sludge application at recommended rates increased microbial activity in soil and tied up the heavy metals making them unavailable to plant and soil [10]. Another factor which needs careful attention regarding the use of sewage sludge/biosolids is prevalence of pathogens. It contains pathogenic bacteria, viruses and protozoa along with other parasitic helminthes, which can give rise potential health hazards to human, animals and plants. Salmonella and Taenia were identified as the greatest concern and risk to health from microbes in sewage sludge applied to land [11]. The number of pathogenic and parasitic organisms in sludge can be significantly reduced before application to land by appropriate sludge treatment and potential health hazard is further reduced by the effect of climate, soil microorganism and time after the sludge is applied to the soil [4].

Information on all these aspects in Pakistan and many under developed countries is limited and scanty. Therefore, this review paper focuses discussion on these important issues so that conclusions can be drawn as how for the sewage sludge is useful in sustaining soil quality and agricultural productivity.

\section{Characterization of Sewage Sludge}

There is an interesting trend in the agricultural application of sewage sludge obtained from wastewater treatment plant due to the possibility of recycling valuable components: organic matter, N, P and other plant nutriaents. Characterization of sewage sludge is extremely important prior to sludge disposal or application to farm land because there is a risk of toxic elements accumulation in soil $[12,13]$. Moreover, there is potential health hazard due to pathogens in the sewage sludge. The content of the sewage sludge will depend on the original pollution load of the treated water, treatment process applied to waste water and sludge [14]. Sludge treatment affects its composition. Examples of effective sludge treatment processes are presented in Table $\mathbf{1}$ and various types of sludge used in European countries are given in Table 2.

\subsection{Fertility Parameters of Sewage Sludge}

\subsubsection{Organic Matter and Major Nutrients}

Organic matter content and major nutrients were found to be quite high in sludge (Table 3). These are the parameters which are considered essential for enhancing soil fertility/quality and sustaining soil productivity.

Table 1. Effective sludge treatment processes.

\begin{tabular}{|c|c|}
\hline Process & Descriptions \\
\hline $\begin{array}{l}\text { Sludge } \\
\text { pasteurization }\end{array}$ & $\begin{array}{l}\text { Minimum of } 30 \text { minutes at } 70^{\circ} \mathrm{C} \text { or minimum of } 4 \text { hours at } 55^{\circ} \mathrm{C} \text { (or appropriate intermediate conditions), followed in all cases } \\
\text { by primary mesophilic anaerobic digestion. }\end{array}$ \\
\hline $\begin{array}{l}\text { Mesophilic } \\
\text { anaerobic } \\
\text { digestion }\end{array}$ & $\begin{array}{l}\text { Mean retention period of at least } 12 \text { days primary digestion in temperature range } 35^{\circ} \mathrm{C} \pm 3^{\circ} \mathrm{C} \text { followed in each case by a } \\
\text { secondary stage which provides a mean retention period of at least } 14 \text { days. }\end{array}$ \\
\hline $\begin{array}{l}\text { Thermophilic } \\
\text { aerobic digestion }\end{array}$ & $\begin{array}{l}\text { Mean retention period of at least } 7 \text { days digestion. All sludges are to be subjected to a minimum of } 55^{\circ} \mathrm{C} \text { for a period of at } \\
\text { least } 4 \text { hours. }\end{array}$ \\
\hline $\begin{array}{l}\text { Composting } \\
\text { (windows or } \\
\text { aerated piles) }\end{array}$ & $\begin{array}{l}\text { The compost must be maintained at } 40^{\circ} \mathrm{C} \text { for at least } 5 \text { days and for } 4 \text { hours during this period at a minimum of } 55^{\circ} \mathrm{C} \text { within } \\
\text { the body of the pile followed by a period of maturation adequate to ensure that the compost reaction is substantially complete. }\end{array}$ \\
\hline $\begin{array}{l}\text { Lime } \\
\text { stabilization of } \\
\text { liquid sludge }\end{array}$ & $\begin{array}{l}\text { Addition of lime to raise } \mathrm{pH} \text { to greater than } 12.0 \text { and sufficient to ensure that the } \mathrm{pH} \text { is not less than } 12 \text { for a minimum period } \\
\text { of } 2 \text { hours. The sludge can then be used directly. }\end{array}$ \\
\hline Liquid storage & Storage of untreated liquid sludge for a minimum period of 3 months. \\
\hline $\begin{array}{l}\text { Dewatering } \\
\text { and storage }\end{array}$ & $\begin{array}{l}\text { Conditioning of untreated sludge with lime or other coagulants followed by dewatering and storage of the cake for minimum } \\
\text { period of } 3 \text { months if sludge has been subjected to primary mesophilic anaerobic digestion, storage to be a minimum period of } \\
14 \text { days. }\end{array}$ \\
\hline
\end{tabular}

Source: [15]. 
Table 2. Different types of sludge used in Europe.

\begin{tabular}{|c|c|}
\hline Sewage sludge & Method of production and some important characteristics \\
\hline Liquid sludge & $\begin{array}{l}\text { It is produced by sedimentation of screened sewage and contain between } 2 \% \text { and } 7 \% \text { dry solid. Up to } 75 \% \text { of the solid } \\
\text { fraction is organic matter. }\end{array}$ \\
\hline Untreated sewage cake & $\begin{array}{l}\text { The sludge cake is formed by dewatering of liquid sludge and has a consistency similar to soil. Microbiologically, } \\
\text { untreated cake is comparable to farm yard manure. }\end{array}$ \\
\hline $\begin{array}{l}\text { Conventionally treated } \\
\text { sludge }\end{array}$ & The sludge is subjected to digestion to ensure a $99 \%$ reduction in microbiological content. \\
\hline $\begin{array}{l}\text { Enhanced treated } \\
\text { sludge }\end{array}$ & $\begin{array}{l}\text { The sludge is treated through various processes, which eliminate the pathogen altogether. Techniques include drying of } \\
\text { sludge to form granules ( } 98 \% \text { dry solid), lime pasteurization or digestion, followed by heat treatment. }\end{array}$ \\
\hline Composted sludge & $\begin{array}{l}\text { Dewatered undigested sludge composts most readily. Composted sludge is odorless friable soil like material. Cereal } \\
\text { straw or any other agent is added to the sludge to enhance aeration. The availability of } \mathrm{N} \text { in the composted material is } \\
\text { low but relatively rich in P. }\end{array}$ \\
\hline Lime treated sludge & $\begin{array}{l}\text { Undigested sludge cake is mixed with lime or waste lime materials in controlled condition to produce friable and easily } \\
\text { handleable product. The } \mathrm{pH} \text { of the product is high which throw off ammonia reducing } \mathrm{N} \text { content and availability of P. }\end{array}$ \\
\hline
\end{tabular}

Source: [16,17].

Table 3. Organic matter content and major nutrients in sewage sludge.

\begin{tabular}{ccc}
\hline Fertility parameters & Pakistan $^{\mathbf{a}}$ & India $^{\mathbf{b}}$ \\
\hline Organic matter $\left(\mathrm{mg} \cdot \mathrm{kg}^{-1}\right)$ & 19,400 & - \\
Total nitrogen $\left(\mathrm{mg} \cdot \mathrm{kg}^{-1}\right)$ & 16,000 & $15,400-19,200$ \\
Available $\mathrm{N}\left(\mathrm{mg} \cdot \mathrm{kg}^{-1}\right)$ & 5200 & $4600-6300$ \\
Available P $\left(\mathrm{mg} \cdot \mathrm{kg}^{-1}\right)$ & 70 & $44-60$ \\
Available $\mathrm{K}\left(\mathrm{mg} \cdot \mathrm{kg}^{-1}\right)$ & 288 & $290-410$ \\
\hline
\end{tabular}

\subsubsection{Micronutrients and Heavy Metals}

The issue of micro-nutrient and heavy metal concentration in sewage sludge needs careful attention for its use in agriculture. If the concentration of heavy metals is high in the sewage sludge then its continuous use year after year may result in toxic accumulation of heavy metals in the soil, which may have phytotoxic effects on various cereals, vegetables, fruits, pastures, and fodder crops. Consumption of these commodities by human beings and animals can cause health hazards to them. It is, therefore, essential to determine the heavy metal content of sewage sludge before its recommendation for use in agriculture.

Table 4 gives critical concentration of heavy metals in sewage sludge in different countries. Sewage sludge with heavy metal concentration higher than critical level for a given country is not permitted to be used as organic fertilizer for that country. In general, Germany is stricter than United States and European member states with regard to critical levels as shown by the lower values imposed by Germany. Heavy metal ranges in sewage sludges of European member states (Table 4) are comparatively lower than critical level adopted by them. In India the heavy metal ranges were higher than ranges in the European member states (Table 5). However, these values were either lower or closer to those mentioned in Table 4.

\subsection{Microbial Pathogens in Sewage Sludge}

Microbial analysis of the sewage sludge revealed that sewage sludge contained wide range of microbial pathogens (Tables 6 and 7). Since the sludge under discussion was from municipal channels, therefore, main source of pathogens in sewage sludge is believed to be human faeces. Treatment of the sewage sludge is, therefore, extremely essential for its use in agriculture in order to avoid health risks.

\section{Environmental Implication of Sewage Sludge Used in Agriculture}

\subsection{Impact on Soil Quality and Fertility}

Microbial activities are vital for maintaining soil quality and soil fertility. Sewage sludge has the potential to enhance soil productivity because it contains high organic matter and plant nutrient content. At the same time, sewage sludge can pose a serious threat to human health and ecosystem because of heavy metals and toxic organic compounds. Research on the land application of sewage sludge has mainly focused on its role in the introduction of heavy metals in the food chain. There is limited information as how sewage sludge application can influence soil microbial and biochemical characteristics with respect to maintaining soil quality. 
Table 4. Critical levels of heavy metals $\left(\mathrm{mg} \cdot \mathrm{kg}^{-1}\right)$ in sewage sludge.

\begin{tabular}{|c|c|c|c|c|}
\hline \multirow{2}{*}{$\begin{array}{c}\text { Heavy metal } \\
\text { Arsenic }\end{array}$} & \multirow{2}{*}{$\begin{array}{c}\text { 86/278/EEC } \\
\text { Japan }\end{array}$} & \multirow{2}{*}{$\begin{array}{c}\text { Country } \\
\text { US } \\
-\end{array}$} & \multicolumn{2}{|c|}{$\begin{array}{c}\text { EC Directiv } \\
\text { Germany }\end{array}$} \\
\hline & & & 50 & - \\
\hline Cadmium & 85 & 10 & 5 & $20-40$ \\
\hline Chromium & 3000 & 900 & - & $1000-1750$ \\
\hline Copper & 4300 & 800 & - & $1000-1750$ \\
\hline Lead & 840 & 900 & - & $750-1200$ \\
\hline Mercury & 57 & 8 & 2 & $16-25$ \\
\hline Nickle & 420 & 100 & - & $300-400$ \\
\hline Zinc & 7500 & 2500 & - & $2500-4000$ \\
\hline
\end{tabular}

Source: [14,20-22].

Table 5. Micronutrients and heavy metals in sewage sludge.

\begin{tabular}{|c|c|c|c|}
\hline Micronutrient/heavy metals & ${ }^{\mathrm{a}}$ Range in the European union member states & ${ }^{\mathrm{b}}$ Range in India & ${ }^{\mathrm{c}}$ Pakistan \\
\hline \multicolumn{4}{|c|}{$\left(\mathrm{mg} \cdot \mathrm{kg}^{-1} \mathrm{DM}\right)$} \\
\hline As & - & $8-23$ & - \\
\hline $\mathrm{Fe}$ & - & - & 250 \\
\hline $\mathrm{Mn}$ & - & - & 210 \\
\hline $\mathrm{Cu}$ & $39-361$ & - & 202 \\
\hline $\mathrm{Zn}$ & $142-2000$ & - & 640 \\
\hline $\mathrm{Cd}$ & $0.4-3.8$ & $2-9$ & - \\
\hline $\mathrm{Cr}$ & $16-275$ & $66-1098$ & - \\
\hline $\mathrm{Hg}$ & $0.3-3$ & $7-32$ & - \\
\hline $\mathrm{Ni}$ & $9-90$ & $12-596$ & - \\
\hline $\mathrm{Pb}$ & $13-221$ & $26-154$ & - \\
\hline
\end{tabular}

a[14], ${ }^{\mathrm{b}}[19],{ }^{\mathrm{c}}[18]$.

Table 6. Microbial contaminations in sewage sludge, D. I. Khan, Pakistan.

\begin{tabular}{ll}
\hline Bacteria & Fungi \\
\hline Salmonella spp. & Aspergillus spp. \\
Escherichia coli & Alternaria spp. \\
Staphylococcus aureus & Geotrichum spp. \\
Proteus spp. & Mucor spp. \\
Pseudomonas spp. & Rhizopus spp. \\
Streptococcus spp. & Penicillium spp. \\
Bacillus subtilis & - \\
\hline
\end{tabular}

Table 7. Pathogens found in municipal wastewater and sewage sludge.

\begin{tabular}{llll}
\hline Bacteria & Viruses & Protozoa & Fungi \\
\hline Salmonella spp. & Poliovirus & Cryptosporidium & Aspergillus spp. \\
Shigella spp. & Coxsackievirus & Entamoeba histolytica & \\
Yersinia spp. & Echovirus & Giardia lamblia \\
Vibrio cholerae & Hepatitis A virus & Balantidium coli \\
Campylobacter jejuni & Rotavirus & Toxoplasma gondii \\
Escherichia coli (pathogenic strains) & Human caliciviruses & Helminths worms \\
Clostridium perfringens & Reovirus & Ascaris lumbricoides \\
Legionella pneumophila & Hepatitis B, C \& E virus & Trichuris trichiura \\
Listeria monocytogenes & ASTROVIRUSES & Toxocara canis \\
Staphylococcus aureus & Adenoviruses & Taenia solium & \\
Leptospira & & Necator americanus \\
Icterohaemorrhagiae & & Hymenolepis nana \\
\hline
\end{tabular}

Source: [23]. 
The effects of heavy metals on soil microbial community with emphasis on specific microbial activities have been well documented [24]. Generally the application of low metal sludge have beneficial effects on microbial biomass, organic carbon and on soil microbial activity, whereas higher heavy metal contamination of soils resulted in considerable decrease in biomass carbon [25, 26], soil microbial biomass level and activities of soil micro organism [27-29]. This could have permanent adverse effects on soil quality. Some researchers investigated the effect of sewage sludge application on biological and biochemical properties of soil on receiving single and multiple applications of 0,50 and 100 tons of sludge $\mathrm{ha}^{-1}$ [30]. Sludge application significantly increased the amount of microbial biomass in the soil. The biomass $\mathrm{N}$ content was uncharacteristically low, resulting in a mean microbial biomass C:N ratio of 36:1. Despite the wide C: $\mathrm{N}$ ratio, sludge application enhanced $\mathrm{N}$ mineralization potential of soil. Sludge application somewhat increased activities of important soil enzyme (arylsulfatase, acid phosphatase, and alkaline phosphatase). Highest rate of sludge application $\left(200 \mathrm{t} \cdot \mathrm{ha}^{-1}\right)$ was found to significantly reduce functional diversity of soil community. Although sludge application resulted in a reduction of diversity of the microbial population, overall size of the soil microbial biomass and its inherent mineralization potential were unchanged or increased. Manguiat [31] also reported that sewage application did not affect the mineralization of soil organic nitrogen.

Degradation of the organic matter applied in sludge increases the available fraction of nutrients e.g. nitrogen and phosphorus. Application of sewage sludge at a rate of $200 \mathrm{t} \cdot \mathrm{ha}^{-1}$ increased the total nitrogen of soil aggregates by $57 \%$ and available phosphorus by $64.2 \%$ [32]. Phosphorus and nitrogen are released more slowly through degradation of organic matter than in case of inorganic fertilizers and, therefore, the compounds are available for longer period [33]. Organic matters in the sludge mainly consist of soluble matter with a small amount of lignin and cellulose that contribute to its composition. That is why the organic matter within the sludge has the potential to mineralize relatively quickly. This potential rapid degradation could lead to a peak in nitrate and phosphorus levels within the soil [34].

\subsection{Impact on Soil Physical Properties}

Sewage sludge is a rich source of organic matter. Organic content of sludge in urban sewage is generally high, usually more than $50 \%$ of dry matter. Addition of organic matter in the form of sewage sludge will have profound effect on soil physical properties and positive soil conditioning effect on most soils. The improved aeration and drainage following sludge amendments can have indirect effects on soil-plant relationships of heavy met- als through affecting growth [35]. Effects of sewage sludge/biosolids on soil physical properties such as increased soil aggregate formation and stability may be greater than for animal manures due to stability of organic compounds in biosolids. Improved water infiltration is important especially on upland areas where the top soil is shallow and low in organic matter due to soil removal by erosion and grading in terrace formation [36]. Increasing rate of sewage sludge for growing wheat decreased the bulk density and increased total porosity. In several other studies on agricultural use of amendments consistently showed decrease in the bulk density and penetration resistance with increasing rates of amendment [37-40]. Reported decreases in bulk density are attributed to increase in aggregate stability and total porosity [37]. Addition of sludge to sandy loam soil increased soil aggregates stability by $41 \%$ while addition to clay had no significant effect [41]. It also increased the water holding capacity of soil $[42,43]$. Top soil available capacity was increased with increasing rates of sludge application. Improvement in soil physical properties will result in increased soil filtration rate, reduction in surface run off and water erosion [33]. The foregoing discussion leads to conclusion that use of biosolids on farm land definitely improves soil physical conditions which is considered extremely essential in sustaining soil productivity.

\subsection{Impact on Soil Microbial Properties}

In general, addition of organic manure in the form of sewage sludge will increase soil microbial activities, their population and microbial biomass. Consequently the soil life goes through a considerable changing. Application of sludge containing low concentration of heavy metals improved soil microbial activities [28,44]. However, elevated metal concentration have been shown to reduce soil microbial biomass levels, inhibit nitrogen fixation by both free living and symbiotic micro-organisms and reduce enzyme activities [45,46]. Since in calcareous alkaline soils metal get fixed into the soil, therefore, any adverse effect on microbial biomass will be temporary. Ultimately the microbial population/biomass will increase and their activities will enhance. High levels of sludge application (200 ton $\cdot \mathrm{ha}^{-1}$ ) significantly reduced the functional diversity of soil community but overall size of the soil microbial biomass and its inherent mineralization potential were either unchanged or increased [30].

\subsection{Impact of on Soil Chemical Characteristics}

Addition of sewage sludge to an agricultural soil will increase organic matter content in the soil, which leads to production of humic and carbonic acids that play a fun- 
damental role in conditioning soil properties. These acids in calcareous soils will lower the soil $\mathrm{pH}$. In an experiment conducted on calcareous soil, increasing rates of sewage sludge (up to $100 \mathrm{t} \cdot \mathrm{ha}^{-1}$ ) only after one year reduced soil $\mathrm{pH}$ from 8.2 to 8.0 [18]. Humic substances have high cation exchange sites. Thus addition of sewage sludge to soil with low cation exchange capacity over period will increase organic matter, which ultimately increases the cation exchange capacity of the soil [41]. Humic substances extracted from sewage sludge strongly interact with pesticides to speed up their biodegradation, and with metal ions influence their transport and plant accessibility. They also act as a potential source of nutrients for plants in addition to their ability to buffer soil $\mathrm{pH}$ and xenobiotic organic molecule retention. Moreover, there is high percentage of nitrogen content bound by humic like substances in sewage sludge and compost which is one of the main criterions of usefulness of sewage sludge compost for agricultural purposes. A better overall decomposition process of sewage sludge is possible through better accessibility of the substrate component for microbiological conversion and application of new types of microorganisms, such as hyperthermophilic microorganisms or genetically modified microorganisms which may be an interesting research for the treatment of sewage sludge in the future [47]. Sewage sludge decomposition is essential because noncomposted or immature compost applied to agricultural soils may cause phytotoxicity to plants, nitrogen and oxygen deficiency and adversely affect the environment [48].

\subsection{Impact on Availability of Heavy Metals and Pollution}

Almost all types of sewage sludge contain heavy metals. Heavy metals such as cadmium, copper, nickel, lead, zinc, mercury, and chromium which originate in sewage are regarded as potentially toxic elements. With the application of sewage sludge, heavy metals also enter the soil by atmospheric deposition from both natural and anthropogenic sources. Metals may be removed from the soil through plant uptake, wind/water erosion, leaching and runoff. On certain soils e.g. copper deficient soils, heavy metals in sewage sludge can correct element deficiency [14]. When sewage sludge is applied to soil, equilibrium between the soil and liquid phase of the heavy metal applied with the sludge will be established [14]. Strong binding between components of soil and heavy metals from sewage sludge causes heavy metals to be retained in the upper layers, where they are applied with concentration decreasing rapidly with depth. It has been found that mean layers of soil enriched in heavy metals are $0-15 \mathrm{~cm}$ and $15-40 \mathrm{~cm}$, approximately equivalent to depth of incorporation of the sludge [14]. Incorporation of sludge into agricultural soils in UK would rarely exceed $30 \mathrm{~cm}$, the depth of sampling. Factors that influence the movement of metal within the soil include soil $\mathrm{pH}$, cation exchange capacity (CEC), organic matter content, temperature, soil humidity, soil structure and soil type. The most important factor controlling the movement of metals in soil is $\mathrm{pH}$ and it is considered to be the most effective and rapid method of controlling the bioavailability of heavy metals in sludge treated soil. Soil $\mathrm{pH}$ influences the precipitation and dissolution of insoluble hydroxide and formation of mineral organic complexes [49]. Increasing the $\mathrm{pH}$ also increases adsorption of heavy metals on clay and organic matter. SNIFFER [34] based on scientific evidence suggested that there should be single figure metal limit for soils in the $\mathrm{pH}$ range 5 - 7 and that sludge should not be applied to agricultural soils with $\mathrm{pH}$ lower than 5 . Higher soil metal limits could be safely set for soil of $\mathrm{pH}$ greater than 7 containing at least 5\% calcium carbonate. Majority of Pakistan and other countries' soils under arid environment are calcareous alkaline with $\mathrm{pH}$ ranging from 7.5 to 10 or even more and lime content ranging from $5 \%$ to $20 \%$. On arid lands where rain fall varies from 150 to $250 \mathrm{~mm}$, lime contents may be as high as $40 \%$. Therefore, the use of sewage sludge with moderate level would not be a problem because the metals will be precipitated/ adsorbed on the clay particle.

Organic matter of the sewage sludge is other important factor which controls the bioavailability of heavy metals in soil. It is a very important adsorptive medium for trace metals in the soil [50]. Soluble organic matter from sludge has two groups of exchange sites, one binding $\mathrm{Ca}$, $\mathrm{Mg}, \mathrm{Zn}, \mathrm{Ni}, \mathrm{Co}, \mathrm{Mn}, \mathrm{Cd}, \mathrm{Pb}$, and $\mathrm{Fe}$ and the other binding only $\mathrm{Cu}, \mathrm{Pb}$, and $\mathrm{H}$ [51]. Free metal activity in soil solution was found to be significantly reduced by organic ligands [52].

Bioavailability of $\mathrm{Cd}$ is restricted in calcareous soil [53,54]. This is likely to be due to a combination of chemisorptions [55], precipitation of $\mathrm{CdCO}_{3}$ [56] and competition with $\mathrm{Ca}^{2+}$ ion for absorption sites on plant roots. The labile fraction of heavy metals in soil is the most important for toxicity to plants. It is, therefore, crucial to reduce this fraction in sewage sludge contaminated soil to decrease their negative effects. Application of $2 \%(\mathrm{w} / \mathrm{w}) \mathrm{Na}$ benovite, Ca benovite and phosphatic fertilizers especially Novaphos at $0.05 \%(\mathrm{w} / \mathrm{w})$ strongly reduced bioavailability of heavy metals in wheat plant [57]. In Australia the risk of heavy metals present in the sewage sludge regarding their adverse effects on the environment and food chain (when used in agriculture according to the best practices/methods) is not greater than conventional fertilizer (bearing heavy metals). For example, single super phosphate fertilizer sold in Australia contains 3.4 to $24.4 \mathrm{mg} \cdot \mathrm{kg}^{-1}$ cadmium [58]. This concludes that there is a little or no danger of accumulation 
of heavy metals due to application of sewage sludge to high $\mathrm{pH}$ calcareous soil in arid and semiarid regions of the country. However, despite undisputable advantages obtained from the application of sewage sludge in agriculture, it may involve some serious threat in the form of organic pollutants (potentially toxic organic compounds in sewage sludge) [59,60]. It is particularly important, due to its diversified effects on living organisms (mutagenic effect, carcinogenic effect, endocrine disrupting effect) [61]. Organic pollutants and their potential threats are identified with biological tests. The estimation of phytotoxicity with biological tests is extremely important due to its frequent utilization for natural purposes. The application of phytotoxicity tests will evaluate the applicability of sewage sludge for agricultural or soil reclamation purposes, and also to identify potential threats for the environment and human health. Research results revealed that level of phytotoxicity depends on soil type, species of plants grown, and nature of sewage sludge [62]. Some researchers have reported that sewage sludge can be used as biomass resource for the production of energy (heat, electricity, or biofuel) which is then used as energy source in the production of cement or building materials [47]. In these processes, the toxic organics are destructed and the heavy metals are immobilized in the ash or cement.

\subsection{Impact on Pathogens in Soil}

The biggest objection on the use of sewage sludge in agriculture is accumulation of pathogenic organisms in soil $[36,63]$. Sewage sludge contains pathogenic bacteria, viruses and protozoa, which can give rise to potential hazards to the health of human, animals and plants. The number of pathogenic and parasitic organisms in sewage sludge can be significantly reduced before application to the land by appropriate sludge treatment [4]. Pathogenic micro-organism can be eliminated by the use of sewage sludge such as untreated sewage cake, conventionally and enhanced treated and composted sludge [34]. Irradiation is another approach for decontaminating sewage sludge. It involves exposure to gamma radiation. The gamma radiation induces ionization of biological tissues and subsequently cell protoplasm is damaged, hence, the pathogen is inactivated [31]. Once applied to land, pathogens are removed from the sewage sludge by filtration, adsorption by soil constituents and natural die off [63, 64].

Pathogens survival in the soil is dependent on numerous direct and indirect factors. Indirect factors include climatic factors (e.g. sunlight, temperature, desiccation or $\mathrm{pH}$ ), characteristics of soil (e.g. texture and moisture), quantity of sludge, its organic content and presence of competing and predating micro-organism. Direct factors include the biological characteristics of pathogens in question especially the form in which it is applied to soil e.g. spore [14,17]. The main factors and environmental conditions influencing the pathogen survival are summarized in Table 8.

Depending on the conditions and organisms themselves, survival period vary from a few days to several years in some cases. Parasites, eggs or cysts are the longer survivors, surviving one to two years in certain favorable circumstances [14]. Pathogen survival times are longest in moist, cold soils and shortest in dry warm soils [41,65]. About $68 \%$ of Pakistan falls in arid and semi arid region where summer temperatures range from $40^{\circ} \mathrm{C}-52^{\circ} \mathrm{C}$ and rain fall is low. Under these agro-environmental conditions, pathogen survival will be in days. Another most important factor influencing the survival of pathogen in soil is competition with existing micro flora. According to research report, newly added micro-organisms may persist for much longer in soil with low microbial activity [66]. However addition of large quantities of sewage sludge to soil is likely to enhance microbial activity in low activity soil thus reducing the survival of pathogens within the soil environment [17] as described in Table 8.

Table 8. Factors influencing pathogen decay in sludge amended soil.

\begin{tabular}{lll}
\hline Factors & Comments \\
\hline Temperature & - & $10^{\circ} \mathrm{C}$ rise increased die-off two fold \\
Moisture content & - & Longer survival in winter than in summer \\
Water holding capacity & - & Decreasing moisture content increased die-off \\
Soil water suction & - & Poor water holding capacity decreased survival \\
& - & Maximum survival in saturated soil \\
Application method & - & Conflicting report for die-off rates for sludge \\
& - & applied to soil surface and incorporated sludge \\
pH & - & Injected sludge may protect organisms \\
Low nutrient availability and competing flora & - & Disking may re-contaminate land \\
\hline
\end{tabular}

Source: [17]. 


\section{Sewage Sludge as Biological Resource for Sustainable Agriculture}

There is an increasing interest in agricultural application of sewage sludge obtained from wastewater treatment plants due to possibility of recycling of valuable components such as organic matter, N, P and other plant nutriaents. Since sewage sludge contains substantial amounts of nitrogen and phosphorus, it can be an effective fertileizer replacement for these important nutrients. In addition to these attributes, it may conserve organic matter and provide an opportunity for its beneficial re-use as a resource in agriculture and reclamation in preference to its disposal. Moreover, organic matter in soils of arid and semi arid regions is low due to rapid oxidation. Maintaining adequate organic matter content is essential for maintaining soil fertility and productivity. Composting municipal solid wastes and sewage sludge is a good way to reduce the amount of wastes generated in densely populated areas and the agronomic use of compost manure is one method to increase organic matter. Composting processes are expected to lower the availability of metals in amended soil. Metals are strongly bound to the compost substance and organic matter, limiting their solubility and potential bioavailability in soil which may protect the soil and environment from potentially negative impacts caused by long-term accumulation of heavy metals in soil [67]. Application of compost and sewage sludge have been shown to have many advantages in- cluding provision of a whole array of nutrients to soil [68, 69], increasing beneficial soil organism, reducing plant pathogen [70] and improving water holding capacity [42]. Besides these advantages, sewage sludge will build and maintain higher soil organic matter levels that will sequester carbon and mitigate greenhouse gas emissions.

\subsection{Use of Sewage Sludge for Crop Husbandry}

Being an important organic fertilizer, sewage sludge is used for crop production in both the developed and developing countries of the world. However, mixed crop responses to sludge application have been reported. In a study on wheat both straw and grain yield increased with increasing rates of sewage sludge application up to 40 $\mathrm{t} \cdot \mathrm{ha}^{-1}$ [18]. Above this level there were declining trends both in straw and grain yields (Table 9). Regression analysis also revealed quadratic trends regarding straw and grain yield in response to increasing sewage sludge level (For straw, $\mathrm{Y}=5.8+0.128 \mathrm{x}-0.001 \mathrm{x}^{2}, \mathrm{R}^{2}=0.947$; for grain yield, $Y=3.21+0.095 x-0.000 x^{2}, R^{2}=0.837$ ). Similarly, Mn, Fe and Zn concentration in leaf tissues (at boot stage) increased significantly with an increasing rate of sewage sludge from 10 to $40 \mathrm{t} \cdot \mathrm{ha}^{-1}$ (Table 10). Cu concentration was higher when sewage sludge was applied at the rate of 10 to $20 \mathrm{t} \cdot \mathrm{ha}^{-1}$. Application of 20 ton of sewage sludge along with half of the recommended dose of NPK produced highest grain yield in wheat, however, it significantly reduced $\mathrm{Mn}, \mathrm{Fe}$, and $\mathrm{Zn}$ con-

Table 9. Effect of different levels of sewage sludge on wheat yield.

\begin{tabular}{ccc}
\hline Sewage sludge $\left(\mathrm{t} \cdot \mathrm{ha}^{-1}\right)$ & Straw yield $\left(\mathrm{t} \cdot \mathrm{ha}^{-1}\right)$ & ${\text { Grain yield }\left(\mathrm{t} \cdot \mathrm{ha}^{-1}\right)}$ \\
\hline 0 & $5.80 \mathrm{~g}$ & $7.21 \mathrm{~g}$ \\
10 & $8.22 \mathrm{f}$ & $5.22 \mathrm{c}$ \\
20 & $9.00 \mathrm{e}$ & $9.15 \mathrm{a}$ \\
40 & $9.40 \mathrm{~b}$ & $5.65 \mathrm{~b}$ \\
60 & $9.30 \mathrm{c}$ & $5.20 \mathrm{~d}$ \\
100 & $8.70 \mathrm{~d}$ & $5.10 \mathrm{e}$
\end{tabular}

Source: [18]. Note: Means followed by same letter do not differ significantly at 5\% level of probability.

Table 10. Effect of sewage sludge application on heavy metal concentration in wheat leaf tissues and grain yield.

\begin{tabular}{|c|c|c|c|c|c|}
\hline \multirow{2}{*}{ Treatments } & \multicolumn{5}{|c|}{ Heavy metals in wheat leaf tissue } \\
\hline & $\mathrm{Cu}$ & $\mathrm{Mn}$ & $\mathrm{Fe}$ & $\mathrm{Zn}$ & Grain yield $t \cdot h a^{-1}$ \\
\hline Control & $8.98 \mathrm{c}$ & $59.8 \mathrm{e}$ & $91.8 \mathrm{e}$ & $22.9 \mathrm{e}$ & $1.67 \mathrm{e}$ \\
\hline *sS@10t·ha ${ }^{-1}$ & $12.53 \mathrm{a}$ & $82.3 \mathrm{c}$ & $123.7 \mathrm{~d}$ & $35.1 \mathrm{~d}$ & $2.17 \mathrm{~d}$ \\
\hline SS@20t·ha ${ }^{-1}$ & 10.65 a & $91.2 \mathrm{~b}$ & $197.0 \mathrm{c}$ & $37.4 \mathrm{c}$ & $2.30 \mathrm{c}$ \\
\hline SS@40 t·ha ${ }^{-1}$ & $9.22 \mathrm{bc}$ & 98.3 a & $245.5 \mathrm{a}$ & $45.6 \mathrm{a}$ & $2.61 \mathrm{~b}$ \\
\hline $\begin{array}{l}\mathrm{SS} @ \underset{\text { (recommended) }}{20 \mathrm{t}^{2} \mathrm{ha}^{-1}+1 / 2 \mathrm{NPK}} \\
\end{array}$ & $10.92 \mathrm{ab}$ & $78.3 \mathrm{~d}$ & $242.0 \mathrm{~b}$ & $42.2 \mathrm{~b}$ & $3.17 \mathrm{a}$ \\
\hline
\end{tabular}

Note: Means followed by same letter do not differ significantly at 5\% level of probability. ${ }^{*}$ Sewage sludge [71]. 
centration in leaf tissue. In Philippine, sewage sludge application increased the yield of upland rice whether applied alone or in combination with $\mathrm{N}$ fertilizer [31]. In Hawaii aerobically digested sludge increased maize biomass whereas two undigested sludges reduced it. At higher rates phytotoxicity resulted from sludge application on roots containing reducible Mn nodules. Adequate supplies of $\mathrm{Ca}$ and $\mathrm{Zn}$ appeared to reduce Mn toxicity [43].

In UK, crop yields were not significantly affected in $60 \%$ of the cases studied, but in $26 \%$ of the cases liquid sludge application resulted in significantly increased crop yield, probably due to beneficial effects on soil structure. Reductions in wheat grain yield, from $6 \%-10 \%$, were noted on the clay soils treated with bed-dried sludge. However, yield reduction was not thought to be due to metals but most likely explanation was lodging of the crop as a result of excessive nitrogen in the soil [4]. Increases in metal concentrations in the soil due to sludge application produced significant increases in $\mathrm{Cd}, \mathrm{Ni}, \mathrm{Cu}$, and $\mathrm{Zn}$ concentrations in the edible portion of the most crops grown; wheat, potato, and rye grass. In most cases there was no significant increase of $\mathrm{Pb}$ in crop tissue in relation to $\mathrm{Pb}$ in the soil from sludge application, suggesting that lead is relatively unavailable to crops from the soil. The availability of metals to crops was found to be lower in soil treated with bed-dried sludge cake compared with liquid sludge [4]. Treated sludge can be applied to growing cereal crops without any constraint. There are no constraints when treated sludge is applied before planting such as cereals, fodder and sugar beet etc. However untreated sludge should be applied or injected into the soil before planting crops [4].

\subsection{Use of Sewage Sludge for Fruit and Vegetable Production}

Fruit and vegetable are consumed by everybody. Use of organic manures for their production is an important input. Fruits and vegetables production need to be further enhanced in view of rapidly growing demographic pressure. Organic manures are not enough to meet the requirements of fruit and vegetable production. Sewage sludge being a valuable input can be used for fruit and vegetable production in view of its high organic matter content and rich macro and micro nutrients. However extreme care is to be taken to avoid the entry of the heavy metals and other organic compounds in the food chain.

Positive effects of sewage sludge on the yield of both summer and winter vegetables have been recorded (Tables 11 and 12). However, yield was the highest when NPK fertilizer was applied at the recommended rate (120-90-60 $\left.\mathrm{kg} \cdot \mathrm{NPK} \cdot \mathrm{ha}^{-1}\right)$. In Jordan, addition of 40 tons $\cdot \mathrm{ha}^{-1}$ sewage sludge (equivalent to the recommended fertilizer rate) increased lettuce growth. Higher rate further increased the lettuce growth, but it resulted in higher plant heavy metal content. Therefore, addition of 40 tons $\cdot \mathrm{ha}^{-1}$ to calcareous soil was recommended to optimize plant growth and minimize adverse effects on plant

Table 11. Effect of sewage sludge on yield of winter vegetables.

\begin{tabular}{|c|c|c|c|}
\hline Sewage sludge $\left(\mathrm{t} \cdot \mathrm{ha}^{-1}\right)$ & Carrot F.W. t $\cdot \mathrm{ha}^{-1}$ & Turnips F.W. t $\cdot \mathbf{h a}^{-1}$ & Radish F.W. t $\cdot h^{-1}$ \\
\hline 0 & $5.75 d$ & $5.32 \mathrm{~d}$ & $4.49 \mathrm{c}$ \\
\hline 25 & $6.25 \mathrm{~cd}$ & 5.99cd & $3.26 c$ \\
\hline 100 & $7.12 \mathrm{bc}$ & $6.25 \mathrm{~cd}$ & $4.97 \mathrm{c}$ \\
\hline 150 & $8.18 \mathrm{~b}$ & $7.74 b$ & $6.57 \mathrm{~b}$ \\
\hline $\mathrm{RDF}^{* *}$ & $12.00 \mathrm{a}$ & $9.94 a$ & $8.10 \mathrm{a}$ \\
\hline
\end{tabular}

"Fresh weight; ${ }^{* *}$ Recommended dose of fertilizer $\left(120-90-60 \mathrm{~kg} \cdot \mathrm{NPK} \cdot \mathrm{ha}^{-1}\right)$ [23]. Note: Means followed by same letter do not differ significantly at $5 \%$ level of probability.

Table 12. Effect of sewage sludge on summer vegetables.

\begin{tabular}{cccc}
\hline & & Summer vegetable & \\
\hline Sewage sludge & Tomato & Onion & Summer squash \\
\hline$\left(\mathrm{t} \cdot \mathrm{ha}^{-1}\right)$ & & & $\left(\mathrm{t} \cdot \mathrm{ha}^{-1}\right)$ \\
0 & $5.56 \mathrm{~d}$ & $4.43 \mathrm{c}$ & $12.25 \mathrm{~d}$ \\
75 & $6.12 \mathrm{~cd}$ & $5.20 \mathrm{cde}$ & $14.9 \mathrm{bc}$ \\
100 & $6.76 \mathrm{~cd}$ & $5.85 \mathrm{bcd}$ & $15.5 \mathrm{bc}$ \\
150 & $8.43 \mathrm{~b}$ & $6.74 \mathrm{ab}$ & $16.6 \mathrm{~b}$ \\
$\mathrm{RDF}^{*}$ & $11.68 \mathrm{a}$ & $7.37 \mathrm{a}$ & $19.8 \mathrm{a}$ \\
\hline
\end{tabular}

*Recommended dose of fertilizer (120-90-60 $\mathrm{kg} \cdot \mathrm{NPK} \cdot \mathrm{ha}^{-1}$ [23]. Note: Means followed by same letter do not differ significantly at $5 \%$ level of probability. 
and soil quality [72]. In another study, addition of sewage sludge at $20,40,80 \mathrm{t} \cdot \mathrm{ha}^{-1}$ increased lettuce yield, head circle, plant height, leaf number, $\mathrm{N}, \mathrm{P}, \mathrm{K}$ and $\mathrm{Mg}$ level to some extent. Leaf Cd concentration increased in sludge treated plots. Sewage sludge application increased organic matter, total $\mathrm{N}$, exchangeable $\mathrm{P}$, exchangeable $\mathrm{K}$, AB-DPTA extractable $\mathrm{Mn}, \mathrm{Cu}$, and $\mathrm{Cd}$ concentration of top soil [73]. It was concluded that sewage sludge could be an alternative to manure to enrich organic matter, and rectify $\mathrm{N}, \mathrm{P}, \mathrm{Fe}$ and $\mathrm{Zn}$ deficiencies in high $\mathrm{pH}$ and calcareous soils.

In Spain, findings of study conducted on citrus to assess the potential of using sewage sludge as an alternative to chemical fertilizer, revealed that use of sewage sludge was suitable to fertilize 3 - 4 years old citrus trees. Nitrogen availability was adequate for root uptake and for satisfactory leaf $\mathrm{N}$ levels and growth [74]. However one should be cautious regarding the use of sewage sludge for horticultural crops. Sewage sludge must not be applied to growing soft fruits or vegetable crops [15]. The growth of the cauliflower, cabbage and potato from field receiving sewage sludge for long periods was depressed and different plant parts showed phytotoxicity symptoms [75]. Vegetables growing near the discharge point contained the maximum amounts of heavy metals which were above toxic limits of these elements, e.g. accumulation of $\mathrm{Cr}$ in potato.

\subsection{Use of Sewage Sludge in Dairy Pastures}

The main potential use of sewage sludge/biosolids is as a fertilizer and/or soil conditioner to improve growth of the dairy pasture and maintain the structure of soil. Sewage sludge supply a range of valuable plant nutrients such as nitrogen, phosphorus, iron, calcium, magnesium and various other macro and micronutrients. Many of these nutrients are also essential component of the healthy diet of a cow for maintaining growth and milk production [76]. Moreover, sewage sludge contains a significant amount of organic matter (approximately 40\% - 60\%) which improves soil structure by increasing soil aeration and water holding capacity of the soil [58].

In Australia where sludge cake biosolids were applied at $0,30,60$ and $120 \mathrm{dry} t \cdot \mathrm{ha}^{-1}$ to sheep grazing pasture, biosolids reduced run off and increased surface retention of rain fall. There was low concentration of metals in the runoff water. Thus there was no concern of the environmental pollution. However $\mathrm{NO}_{3}$ movement was observed up to $50-70 \mathrm{~cm}$ in sandy red earths [5] when biosolids were used for dairy pastures. They must be injected or incorporated into the soil by ploughing. This would minimize the risk of pathogen intake in animals directly ingesting the biosolids in large quantities [2].

With holding periods for which animals should not be allowed to graze on pasture treated with sewage sludge should be adhered too to minimize pathogen and chemical contamination risks. This include all livestock from the time of biosolids application for at least 4 weeks, and for lactating stock and new born animals at least 12 weeks [58]. Treated sludge should not be applied to growing turf within 3 months of harvesting. Other practices that reduce the chances of pathogens being transferred in to the milk are: that biosolids should not be applied to muddy/water logged pasture; injection method of biosolids application into the soil and/or incorporation/ ploughing of biosolid in to the soil should be encouraged [6].

\subsection{Use of Sewage Sludge in Forestry}

The overall goal of sewage sludge addition to forestry is to improve physical, chemical and biological properties of soil and fertility status for creating more favorable conditions for establishment of vegetation or improve plant growth in the existing forests [14]. Untreated sludge cake is mostly used in the forestry. When considering reforestation, land spreading may be carried out prior to planting. In intensive forestry production sludge application may be performed just after sowing, thinning, or clear filling. In established forest, sludge application could potentially occur throughout the year, if good practices are observed and local conditions are acceptable.

Application of sewage sludge in excess can add excessive amount of nutrients to soil, which can directly damage the trees, and create risk to the environment. Excessive use of sludge can also cause an increase in the proliferation of weeds [77].

\section{Conclusion}

On the basis of above review it can be concluded that sewage sludge is very important biological organic fertilizer/soil conditioner for sustainable agriculture. It improves organic matter status of the soil. It also adds macro and micronutrients to the soil. Improvement in organic matter content in soil helps in improving soil physical conditions, rejuvenating soil health and stimulating biological activity. Generally positive effects of application of sewage sludge have been reported on cereals, vegetable and horticultural plants, pastures and forestry. Regarding the danger of toxic accumulation of heavy metals in soil it is well documented that the heavy metals and micronutrients are rendered unavailable due to precipitation in calcareous alkaline soils. Also these metals can be immobilized due to organic materials in the sewage sludge through formation of stable complexes. In other words, organic matter in sewage sludge reduces the negative environmental effects of heavy metals and other pollutants by binding contaminants. Higher level of soil organic matter can sequester carbon and mitigate 
greenhouse gas emissions. Regarding the pathogen in sewage sludge, their number can be significantly reduced before application to soil by appropriate sludge treatments. An enhanced microbial activity due to addition of sewage sludge reduces the survival of the pathogens in soil. Application of sewage sludge to dry soil in warmer region of the countries, 2 to 3 months ahead of seeding the crop will eliminate most of the pathogens from the soil. Therefore, use of sewage sludge in agriculture will be appropriate and beneficial, if applied according to appropriate guidelines to minimize environmental and ecological damage and maximize potential benefits for sustained agricultural productivity. However, sewage sludge prior to use in agriculture must be subjected to evaluation tests for determining the basic physicochemical properties, content of pollutants or pathogenic bacteria, and also ecotoxicological properties in order to avoid the risk of potential threats for the environment and for human health.

\section{REFERENCES}

[1] United States Environmental Protection Agency, "US Consumer Product Safety Commission,” The Inside Story: A Guide to Indoor Air Quality, EPA-402-R-93-013, 1993.

[2] Victoria Environmental Protection Authority, "Environmental Guidelines for Biosolids Management-Draft," EPA Government of Victoria, 2000.

[3] P. Csattho, "The Heavy Metal Pollution of the Environmental and the Agricultural Production,” Tematikus szakirodalmi Szemle, Akaprint Kiado, Budapest, 1994, pp. 18-27.

[4] FAO, “Agricultural Use of Sewage," Waste Water Treatment and Use in Agriculture, FAO Irrigation and Drawing Paper 47, Food and Agriculture Organization of the United Nations, Rome, 1992.

[5] W. D. Joshua, L. Michalk, H. Curits, M. Salt and G. J. Osborne, "The Potential for Determination of Soil and Surface Water from Sewage Sludge (Biosolids) in a Sheep Grazing Study," Australia Contaminants and the Soil Environment, Vol. 84, No. 1-3, 1998, pp. 135-156.

[6] K. Long, "The Use of Biosolid (Sewage Sludge) as a Fertilizer/Soil Conditioner on Dairy Pastures,” A Review from a Dairy Food Safety Prospective, Biosolids Report, 2001.

[7] C. D. Tsadilas, T. Masti, N. Barbayiannis and D. Dimoyiannis, "Influence of Sewage Sludge Application on Soil Properties and on the Distribution and Availability of Heavy Metal Fractions," Communication in Soil Science and Plant Analysis, Vol. 26, 1995, pp. 2603-2619. doi:10.1080/00103629509369471

[8] C. F. Tester, "Organic Amendment Effects on Physical and Chemical Properties of a Sandy Soil," Soil Science Society of American Journal, Vol. 54, No. 3, 1990. pp. 827-831. doi:10.2136/sssaj1990.03615995005400030035x

[9] R. M. Sterritt and J. N. Lester, "Mechanism of Heavy
Metal Contamination into Sewage Sludge,” In: L. Hermite and H. Ott, Eds., Processing and Use of Sewage Sludge, Proceedings of 3rd International Symposium, Commission of European Communities, Redel Dordrechi, Brighton, 1993, pp. 172-175.

[10] I. Sastre, M. A. Vicente and M. C. Lobo, "Influence of the Application of Sewage Sludges on Soil Microbial Activity,” Bioresource Technology, Vol. 57, No. 1, 1996. pp. 19-23. doi:10.1016/0960-8524(96)00035-1

[11] WHO, "Report on Risk to Health from Microbes in Sewage Sludge Applied to Land,” EURO Reports and Studies No. 54, Regional Office for Europe, World Health Organization, 1981.

[12] A. Obrador, J. I. Mingot, J. M. Alvarez and M. I. Rico, "Metal Mobility and Potential Bioavailability Organic Matter Rich Soil Sludge Mixture, Effect of Soil Type and Contect Time," Science of the Total Environment, Vol. 206, 1997, pp. 117-126.

[13] E. A. Alvarez, M. C. Mochon, J. C. J. Sanchez and M. T. Rodriguez, "Heavy Metal Extractable Forms in Sludge from Waste Treatment Plants,” Chemosphere, Vol. 47, No. 7, 2002, pp. 765-775.

doi:10.1016/S0045-6535(02)00021-8

[14] European Commission, "Disposal and Recycling Routes of Sewage Sludge Part 3," Scientific and Technical Report, European Commission DG Environment, 2001.

[15] Department of Natural Resources and Environment, "Biosolids in Victoria-Report on Options for Benificial Use of Biosolids,” 1998.

[16] ADAS, "Guidelines for Application of sewage Sludge to Industrial Crop in UK,” 2001.

http://www.Adas.Co.uk/media/publications/ASSIC.PDF\# search $=\% 22$ types $\% 20$ of $\% 20$ sewage $\% 20 \%$ sludge $\% 22$

[17] E. M. Ameh, M. Rogers, J. Cass, F. Perez-Viana and S. R. Smith, "Survival of the Indicator Organism Escherichia coli Industrially Disturbed Soils Reclaimed by Sewage Sludge Amendment," Final Report, Scottish Water and Portcullis Development Ltd. Center for Environmental Control and Waste management, Department of Civil and environmental Engineering, Imperial College, London, 2006.

[18] M. Jamil, M. Qasim and M. Umar, "Utilization of Sewage Sludge on Organic Fertilizer in Sustainable Agriculture,” Journal of Applied Science, Vol. 6, No. 3, 2006, pp. 531-535. doi:10.3923/jas.2006.531.535

[19] S. K. Dubey, R. K. Yadav, P. K. Chatuvedi, B. Goyel, R. Yadav and P. S. Minhas, "Agricultural Uses of Sewage Sludge and Water and Their Impact on Soil Water and Environmental Health in Haryana, India," Abstract of 18th World Congress of Soil Science, Philadelphia, 9-15 July 2006.

[20] A. Wallace and G. A. Wallace, "A Possible Flaw in EPA, New Sludge Rule, Due to Heavy Metal Interactions," Communication in Soil Science and Plant Analysis, Vol. 25, 1993, pp. 129-135. doi:10.1080/00103629409369019

[21] T. Benckiser and T. Simmarmata, "Environmental Impact of Fertilizing Soils by Using Sewage Sludge and Animal 
Waste,” Fertilizer Research, Vol. 37, 1994, pp. 1-22. doi:10.1007/BF00750669

[22] A. Nishimune, "Combinations of Organic and Inorganic Fertilizers for Crop Production,” Extension Bulletin, No. 372, 1993, pp. 1-25.

[23] M. Q. Khan and J. I. Khan, "Impact of Sewage Waste (Effluent and Sludge) on Soil Properties and Quality of Vegetables,” Final/Completion Report of ALP Project, Department of Soil Science, Faculty of Agriculture, Gomal University, Dera Ismail Khan, 2006.

[24] P. C. Brookes. E. Heijnen, S. P. Mc Grath and E. D. Vance, "Soil Microbial Biomass Estimates in Soils Contaminated with Metals," Soil Biology and Biochemistry, Vol. 18, 1986, pp. 383-388. doi:10.1016/0038-0717(86)90042-8

[25] A. FlieBbach, R. Martens and H. H. Reber, "Soil Microbial Biomass and Microbial Activity in Soils Treated with Heavy Metal Contaminated Sewage Sludge,” Soil Biology and Biochemistry, Vol. 26, No. 9, 1994, pp. 1201-1205. doi:10.1016/0038-0717(94)90144-9

[26] B. P. Knight, S. P. Mc Grath and A. M. Chadri, "Biomass Carbon Measurements Substrate Utilization Patterns of Microbial Populations from Soils Amended with Cadmium, Copper or Zinc," Applied Environmental Microbiology, Vol. 663, 1997, pp. 39-43.

[27] G. Tyler, "Heavy Metals in Soil Biology and Biochemistry,” ln: E. A. Paul and J. N. Ladd, Eds., Soil Biochemistry, Vol. 5, 1981, pp. 371-414.

[28] E. Baath, "Effects of Heavy Metals in Soil on Microbial Process and Populations," A Review Water Air Soil Pollutants, Vol. 4, 1989, pp. 335-379.

[29] S. P. McGrath, P. C. Brookes and K. E. Giller, "Effects of Potentially Toxic Metals in Soil Derived from Past Applications of Sewage Sludge on Nitrogen Fixation by Trifolium repens L.," Soil Bioliogy and Biochemistry, Vol. 20, 1988, pp. 415-424. doi:10.1016/0038-0717(88)90052-1

[30] M. R. Banerjee, D. L. Burtonz and S. Depoe, "Impact of Sewage Sludge Application on Soil Biological Characteristics," Agriculture Ecosystem \& Environment, Vol. 66, No. 3, 1997, pp. 241-249. doi:10.1016/S0167-8809(97)00129-1

[31] I. J. Manguiat, "Sewage Sludge; Turning an Environmental Pollutant into an Agriculture Resource,” 2nd Professional Lecture Delivered in Department of Soil Science, University of Philippine, LOS Banos, 1997.

[32] J. S. C. Mbagwu and A. Piccolo, "Carbon, Nitrogen and Phosphorus Concentration in Aggregates of Organic Waste-Amended Soils,” Biological Wastes, Vol. 31, No. 2, 1990, pp. 97-111. doi:10.1016/0269-7483(90)90164-N

[33] ADAS, "Beneficial Effect of Biosolids on Soil Quality and Fertility,” UKW/ROI/SL/08/2, 2000.

[34] SNIFFER, "Human Health and Environmental Impacts of Using Sewage Sludge on Forestry and for Restoration of Derelict Land,” Macaulay Research Consultancy Service, Craigiebuckler, 2007.

[35] J. A. Roberts, W. L. Daiels, J. C. Bell and D. C. Martens, "Tall Fescus Production and Nutrient Status on South
West Virginia Mine Soils,” Journal of Environmental Quality, Vol. 17, 1998, pp. 55-62. doi:10.2134/jeq1988.00472425001700010008x

[36] C. S. Wortmann, "Sewage Sludge Utilization for Crop Production,” Department of Agronomy and Horticulture, University of Nebraska-Lincoln, Lincoln, 2005.

[37] B. J. Lindsay and T. J. Logan, "Field Response of Soil Physical Properties to Sewage Sludge,” Journal of Environmental Quality, Vol. 27, No. 3, 1998, pp. 534-542. doi:10.2134/jeq1998.00472425002700030009x

[38] B. J. Chambers, F. A. Nicholson, M. Aitken, E. Cartmell and C. Rowlands, "Benefits of Biosolids to Soil Quality and Fertility CIWEM,” Water and Environment Journal, Vol. 17, No. 3, 2003, pp. 162-166. doi:10.1111/j.1747-6593.2003.tb00455.x

[39] F. Garcia-Orenes, C. Guerrero, J. Mataix-Solera, J. Navarro-Pedreno, I. Gomez and J. Mataix-Beneyto, "Factors Controlling the Aggregate Stability and Bulk Density in Two Different Degraded Soils Amended with Biosolids," Soil and Tillage Research, Vol. 82, No. 1, 2005, pp. 6576. doi:10.1016/j.still.2004.06.004

[40] C. G. Cogger, "Potential Compost Benefits for Restoration of Soils Disturbed by Urban Development," Compost Science \& Utilization, Vol. 13, No. 4, 2005, pp. 243-251.

[41] K. C. Cameron, H. J. Di and R. G. McLaren, "Is Soil an Appropriate Dumping Ground for Our Wastes?” Australian Journal of Soil Research, Vol. 35, No. 5, 1997, pp. 995-1035. doi:10.1071/S96099

[42] A. T. Wells, K. Y. Chan and P. S. Cornish, "Comparison of Conventional and Alternative Vegetable Farming Systems on the Properties of a Yellow Earth in New South Wales," Agriculture Ecosystem and Environment, Vol. 80, 2000, pp. 47-60. doi:10.1016/S0167-8809(00)00133-X

[43] N. V. Hue and S. A. Ranjith, "Sewage Sludge in Hawaii; Chemical Composition Reactions with Soils and Plants," Water, Air and Soil Pollution, Vol. 72, No. 1, 1994, pp. 265-283. doi:10.1007/BF01257129

[44] D. S. Powlson, "Impact of Heavy Metals on Soil Quality with Respect to Microbial Activity and Production of Crops," Soil Science Department IACR, Rothamsted, MAFF Project Code, SP0120, 2002.

[45] M. Akmal, H. Z. Wang, J. J. Wu and D. F. Xu, "Changes in Enzymes Activity, Substrate Utilization Pattern and Diversity of Soil Microbial Communities under Cadmium Pollution,” Journal of Environmental Sciences-China, Vol. 17, No. 5, 2005, pp. 802-807.

[46] M. Akmal, J. M. Xu, Z. J. Li, H. Z. Wang and H. Y. Yao, "Effects of Lead and Cadmium Nitrate on Biomass and Substrate Utilization Pattern of Soil Microbial Communities," Chemosphere, Vol. 60, No. 4, 2005, pp. 508-514. doi:10.1016/j.chemosphere.2005.01.001

[47] W. Rulkens, "Sewage Sludge as a Biomass Resource for the Production of Energy: Overview and Assessment of the Various Options,” Energy \& Fuels, Vol. 22, No. 1, 2008, pp. 9-15. doi:10.1021/ef700267m

[48] A. Veeken, K. Nierop, V. Wilde and B. Hamelers, "Characterization of $\mathrm{NaOH}$-Extracted Humic Acids during Composting of a Biowaste," Bioresource Technology, 
Vol. 72, 2000, pp. 33-41. doi:10.1016/S0960-8524(99)90096-2

[49] D. J. Walker, R. Clemente and M. P. Bernal, "Contrasting Effects of Manure and Compost on Soil pH, Heavy Metal Availability and Growth of Chenopodium album L. in a Soil Contaminated by Pyretic Mine Waste," Chemosphere, Vol. 57, 2004, pp. 215-135. doi:10.1016/j.chemosphere.2004.05.020

[50] L. D. King and W. R. Dunlop, "Application of Sewage Sludge to Soils High in Organic Matter," Journal of Environmental Quality, Vol. 11, No. 4, 1982, pp. 608-616. doi:10.2134/jeq1982.00472425001100040011x

[51] P. Fletcher and P. H. T. Beckett, "The Chemistry of Heavy Metals in Digested Sludge II, Heavy Metal Complexion with Soluble Organic Matter," Water Research, Vol. 21, 1997, pp. 1163-1172. doi:10.1016/0043-1354(87)90167-9

[52] G. A. ÖConnor, C. ÖConnor and G. R. Cline, "Sorption of Cadmium by Calcareous Soils: Influence of Solution Composition," Soil Science Society of American Journal, Vol. 48, No. 6, 1984, pp. 1244-1247. doi:10.2136/sssaj1984.03615995004800060008x

[53] D. Zabowski and R. J. Zasoki, "Cadmium, Copper and Zinc Adsorption by a Forest Soil in the Presence of Sludge Leachate," Water, Air \& Soil Pollutats, Vol. 36, No. 1, 1987, pp. 103-113. doi:10.1007/BF00450623

[54] B. J. Alloway, I. Thornton, G. A. Smart, J. C. Sherloc and M. J. Quinn, “Metal Availability,” In: H. Morgan, Ed., The Shipham Report: An Investigation into Cadmium Contamination and Its Implication for Human Health, Science of the Total Environment, Vol. 75, 1988, pp. 4169.

[55] P. Papadopoulos and D. L. Rowell, "The Reactions of Cadmium with Calcite Surfaces,” Journal of Soil Science, Vol. 43, 1988, pp. 23-36. doi:10.1111/j.1365-2389.1988.tb01191.x

[56] T. Christensen and J. C. Tjell, "Interpretation of Experimental Results on Cadmium Crop Intake from Sewage Sludge Amended Soil,” In: P. L. Hermite and H. Ott, Eds., Processing and Use of Sewage Sludge, Reidel, Dordrech, 1984, pp. 358-369.

[57] A. R. A. Usman, Y. Kuzyakov, K. Lorenz and K. Stahr, "Remediation of Soil Contaminated with Heavy Metals by Immobilizing Compounds,” Journal of Plant-Nutrition, Soil Science, Vol. 169, No. 2, 2006, pp. 205-212. doi:10.1002/jpln.200421685

[58] A. N. D. Ross, R. A. Lawrie, M. S. Whatmuff, J. P. Kelly and A. S. H. Awad, "Guidelines for the Use for Sewage Sludge on Agricultural Land,” New South Wales Agriculture, 1991.

[59] S. R. Smith, “Organic Contaminants in Sewage Sludge (Biosolids) and Their Significance for Agricultural Recycling,” Philosophy Today A Royal Society, Vol. 367, 2009, pp. 4005-4041.

[60] E. F. Davis, S. L. Klosterhaus and H. M. Stapleton, "Measurement of Flame Retardants and Triclosan in Municipal Sewage Sludge and Biosolids," Environmental International, Vol. 40, 2012, pp. 1-7.

\section{doi:10.1016/j.envint.2011.11.008}

[61] R. P. Singh and M. Agrawal, "Potential Benefits and Risks of Land Application of Sewage Sludge," Waste Management, Vol. 28, No. 2, 008, pp. 347-358.

[62] P. Oleszczuk, "Testing of Different Plants to Determine Influence of Physico-Chemical Properties and Contaminants Content on Municipal Sewage Sludges Phytotoxicity," Environmental Toxicology, Vol. 25, 2010, pp. 3847.

[63] S. D. Pillai, K. W. Widmer, S. E. Dowd and S. C. Ricke, "Occurance of Air Borne Bacteria and Pathogen Indicator during Land Application of Sewage Sludge,” Applied and Environmental Microbiology, Vol. 62, No. 1, 1996, pp. 296-299.

[64] C. P. Geba, C. Wallis and J. L. Melnick, "Fate of Wastewater Bacteria and Viruses in Soil,” Journal of Irrigation and Drainage, Division of American Society of Civil Engineering, Vol. 10, No. 1, 1975, pp. 157-174.

[65] D. Cools, R. Merckx, K. Vlassak and J. Verhaegen, "Survival of E-coli and Enterococcus spp. Derived from Pig Slurry in Soils of Different Texture," Applied Soil Ecology, Vol. 17, No. 1, 2001, pp. 53-804. doi:10.1016/S0929-1393(00)00133-5

[66] G. Bitton, "Wastewater Microbiology,” 3rd Edition, WileyLiss, Hoboken, 2005, p. 746. doi: $10.1002 / 0471717967$

[67] S. R. Smith, "A Critical Review of the Bioavailability and Impacts of Heavy Metals in Municipal Solid Waste Composts Compared to Sewage Sludge,” Environment International, Vol. 35, No. 35, 2009, pp. 142-156. doi:10.1016/j.envint.2008.06.009

[68] M. Tejada, M. M. Dobao, C. Bentiz and J. L. Gonzalez, "Study of Composting of Cotton Residues," Bioresource Technology, Vol. 79, No. 2, 2001, pp. 199-202. doi:10.1016/S0960-8524(01)00059-1

[69] V. D. Zheljazkov and P. R. Warm, "Source-Separated Municipal Solid Waste Compost Application to Swiss Chard and Basil,” Journal of Environmental Quality, Vol. 33, No. 2, 2004, pp. 542-552. doi:10.2134/jeq2004.0542

[70] G. S. Abawi and T. L. Widmer, "Impact of Soil Health Management Practices on Soil Borne Pathogens, Nematodes and Root Diseases of Vegetable Crops,” Applied Soil Ecology, Vol. 15, 2000, pp. 37-47. doi:10.1016/S0929-1393(00)00070-6

[71] H. Huma and M. Mushtaq, "Effects of Sewage Sludge Application on the Heavy Metal Content of Wheat," Canadian Journal of Soil Science, Vol. 3, 2003, pp. 240248.

[72] M. J. Mohammad and B. M. Athamneh, "Changes in Soil Fertility and Plant Uptake of Nutrients and Heavy Metals in Response to Calcareous Soils,” Journal of Agronomy, Vol. 3, No. 3, 2004, pp. 229-236. doi:10.3923/ja.2004.229.236

[73] A. Sonmez and M. A. Bozkurt, "Lettuce Grown on Calcareous Soils Benefit from Sewage Sludge," Acta Agriculturae Scandinavica B, Vol. 56, No. 1, 2006, pp. 17-24. doi:10.1080/09064710510005813

[74] E. Romeo, V. Flors, P. Garcia-Agustin, M. Cerezo and L. 
Lapena, "Aquifer Contamination by Nitrogen after Sewage Sludge Fertilization," Bulletin of Environmental Contamination and Toxicology, Vol. 72, No. 2, 2004. pp. 344-351. doi:10.1007/s00128-003-8984-9

[75] C. Chatterjee and B. K. Dube, "Impact of Pollutant Elements on Vegetable Growing in Sewage Sludge Treated Soil,” Journal of Plant Nutrition, Vol. 28, No. 10, 2005, pp. 1811-1820. doi:10.1080/01904160500251175
[76] C. W. Holmes and G. F. Wilson, "Milk Production from Pasture,” Butter Worths Agricultural Books, Newzeland, 1984.

[77] INRA, "Epandage de Boues de Station d'Epuration en Conditions Forestieres, Situation Actuelle et Perspectives,” Rapport du Department Forets et Milieux Naturels, Unit de Recherché Forestiere Pierroton, 1999, p. 10. 